\title{
THE IMPORTANCE OF PUBLIC-FUNDED CHARGING STATIONS TO INCREASE THE RATE OF ELECTRIC VEHICLE (EV) OWNERSHIP IN INDONESIA
}

\author{
${ }^{1}$ Faiz Rafiza Ahmadani, ${ }^{2}$ Rafi Aquary \\ ${ }^{12}$ Department of International Relations, Universitas Gadjah Mada, Sleman, Indonesia \\ Ifaiz.rafiza@gmail.com, 2aquarafi@gmail.com
}

\begin{abstract}
The current surplus of electricity across Indonesia has further underlined many opportunities to optimize the usage of electricity in many sectors; including on the issue of Electric Vehicle (EV) ownership within the country. According to the government's projection, the state-owned enterprise (SOE) of PLN would construct 254.181 units of charging stations by 2030. However, there exists the problem of 'chicken and egg'; in which more EV charging stations would be required to spur EV sales and vice versa. In addition to that, the lack of charging stations has also led to the disinterest from the public to purchase EVs due to fear of range anxiety. Hence, this paper is written to address the importance of publicly funded charging stations in Indonesia to help cultivate EV development within the country. Not only that, since Indonesia is the largest member country of ASEAN, it could be the 'trendsetter' of this issue in the region and would have the upper hand position as an early adopter. Our hypotheses suggest that not only publicly funded the development of charging stations would be beneficial to the future-buyer of $\mathrm{EV}$, but also for the government itself.
\end{abstract}

Keywords: Electric Vehicle, Charging Station, Public-Funded, Range Anxiety

DOI: 10.33541/sp.v22i1.3507

Sociae Polites: Majalah IImiah Sosial Politik

Faculty of Social and Political Science, Universitas Kristen Indonesia

ISSN 1410-3745 print/ ISSN 2620-4975 online

Volume 22, Number 1 (Indonesia Clean Energy Conference)

Pages 78-91 


\section{Introduction}

The acceleration of programs that were designed to promote the usage and ownership rate of electric vehicles (EVs) has started to become a worldwide trend, including in Indonesia. Within the country, the push for EV-related policy has become more relevant, especially amidst a rising awareness towards the impacts of $\mathrm{CO}_{2}$ emission which were produced by internal combustion engine (ICE) vehicles; particularly in many urban areas across Indonesia. As an example, it is estimated that around $28 \%$ of energy-related greenhouse gas (GHG) produced in Indonesia mainly comes from the road transport sector (Adiatma and Marciano 2020,1). The rate becomes even more worrying if one takes a look at the data within Indonesian cities. As an example, it is estimated that around $75 \%$ of $\mathrm{CO}_{2}$ emissions in Jakarta came from activities that were related to this sector (Alaidrus 2019). Such concerns on environmental issues also correlate with Indonesia's effort to keep on track with the Paris Agreement which it had ratified since 2016. A consequence of that reality has forced the Indonesian government to push for the increase of EV usage and ownership since the combustion of fossil fuels was approximated as the country's second-largest source of pollution (UNFCCC 2016, 1).

Besides that, the promotion of EVs in Indonesia is inextricably linked with the country's policy in its energy sectors. In this sense, the Indonesian government aimed to reduce the usage of imported fossil fuels (the country has started to become a net oil importer starting from 2004) since it has been a major contributor to the Indonesian balance of trade deficit. Not only that, another energy-related concern that influences this policy also stems from the fact that Indonesia currently has an ongoing electricity surplus. According to the State Electricity Company (PLN), its power supply as of 2020 has a 30\% reserve; or surplus (Asmarini 2020). One of the major explanations regarding this issue was driven by Indonesia's ambitious 35.000 MW megaproject (started in 2014) which aims to fulfill the rising electricity demands, as it was projected that the country's economic growth would reach an average growth of $7 \%$ per year and positively correlate with higher electricity consumptions (Guild 2020). In reality, such a rate of economic growth has not been achieved (which translates into electricity surplus), and it was also exacerbated even further due to the current trend of lower electricity consumption during the COVID19 pandemic in the country. Taking into account all of these factors, the development of EVs in Indonesia has become inevitable and would be more important within the upcoming years.

In order to facilitate its EV growth, Indonesia has started to roll out a significant number of legal frameworks across various governmental bodies within these recent years. One of the most important of all regarding this issue would be the creation of the Presidential Regulation No. 55 of 2019 on Acceleration of Battery Electric Vehicles Program for Road Transportation that was intended to become the country's first comprehensive legislation on EV-related issues. There are several aspects that were discussed within the regulations, namely government subsidies, protection of the environment, manufacturing-related issues for $\mathrm{EV}$, and electricityrelated issues for infrastructures needed for EV development (Dawborn, Donauw, and Sormin 2019). Not only that, but the regulations also discuss the possibility of fiscal incentives to promote locally-produced EV components and to reduce the number of fuel subsidies in the near future by discouraging the ownership of ICE 
vehicles (Dawborn, Donauw, and Sormin 2019). With this in mind, Indonesia has stated that it would try to increase the production of non-ICE vehicles domestically to account for $20 \%$ of all vehicles produced by 2025 , and later on would ban the sales of ICE vehicles by the year 2040 (Kimura, Suehiro, and Doi 2018).

More specifically, on the procurement of charging infrastructure across the country, the Indonesian government has legislated the ESDM Ministerial Regulation No. 13 of 2020 concerning the Provision of Electricity Charging Infrastructure for Battery-Powered Electric Vehicles. Some key issues were being highlighted in this regulation, including outlining the various types of charging infrastructure, stipulations of mandates for the development of battery plug-in electric vehicle (BPEV) charging stations (SPKLU) and BPEV battery exchange station (SPBKLU) through PLN, mandating the state-owned enterprise (SOE) to conduct research on locations, capacities, and business schemes for both models; especially in relations to future business cooperation with the private sectors, and regulating tariffs for charging cost. Other EV-related regulations have also been rolled out recently, including the Government Regulation No.73/2019 regarding the Luxury-Goods Sales Tax (LST) on Motor Vehicles which tries to incentivize the purchase of new EV by setting a $15 \%$ LST rate and $0 \%$ tax base on them, and the Regulation of Minister of Industry Number 27 and 28 of 2020 which outlined the future of domestic EV assembly in the country ("TaxFlash" 2019).

Reflecting on the country's figure on automotive sales, however, it was shown that EVs have not 'made it' within the country, and do not even reach a figure of $1 \%$ of all vehicle sales in 2020 (Rahadiansyah 2021; Nurcahyani 2021). Another factor that came as a significant hindrance for buying EVs in Indonesia also stems from the lack of proper infrastructure, particularly the existence of widely available charging stations. Even though various government efforts have been made to increase the number, its development was still perceived as 'lacking' and could not adequately serve the needs of EV owners. As of January 2021, Indonesia only has around 100 units of charging stations spread over 72 locations which are disproportionately located in the Jabodetabek area (Kurniawan 2021; Hikam 2021). From the perspective of a future EV owner, the 'perceived' lack of charging stations could make them think twice to become a first-time buyer and eventually resort to a more common ICE vehicle. Hence, the promotions for the development of EV charging stations; especially through public funds, should be prioritized by the Indonesian government if it seeks to increase the rate of EV ownership within the country.

Table. 1 Total sale of all hybrid, electric, and plug-in hybrid electric vehicle (PHEV) cars in Indonesia in $\mathbf{2 0 2 0}$ from the members of Gaikindo (The Association of Indonesian Automotive Manufacturers)

\begin{tabular}{|c|l|l|c|l|}
\hline No. & Maker & \multicolumn{1}{|c|}{ Name } & Unit Sales & \multicolumn{1}{c|}{ Type } \\
\hline 1 & \multirow{3}{*}{ Toyota } & Corolla Cross Hybrid & 652 & Hybrid Vehicle \\
\cline { 4 - 5 } & & Camry Hybrid & 130 & Hybrid Vehicle \\
\cline { 4 - 5 } & & C-HR Hybrid & 126 & Hybrid Vehicle \\
\hline
\end{tabular}




\begin{tabular}{|c|c|c|c|c|}
\hline 4 & & Corolla Altis Hybrid & 41 & Hybrid Vehicle \\
\hline 5 & & Prius & 1 & Hybrid Vehicle \\
\hline 6 & Hyundai & Ioniq Electric & 81 & Electric Vehicle \\
\hline 7 & пуйual & Kona Electric & 38 & Electric Vehicle \\
\hline 8 & & i8 & 1 & Hybrid Vehicle \\
\hline 9 & DIVI & i3 & 5 & Electric Vehicle \\
\hline 10 & Nissan & Kicks e-Power & 153 & Hybrid Vehicle \\
\hline 11 & Mitsubishi & Outlander & 6 & PHEV \\
\hline 12 & Lexus & UX 300e & 1 & Electric Vehicle \\
\hline
\end{tabular}

\subsection{Research Question}

How the government's support towards the development of charging stations could spur the growth of EV development in Indonesia?

\subsection{Purpose and Objective}

Even though various studies on the relations between the development of charging stations and increase of ownership has existed, most of it was widely written only on causal relations between the two, and not for the advancement of a certain government policy (which in this paper would be argued through the importance of providing publicly funded charging stations in Indonesia). More specifically, research on these topics which were conducted within the context of policymaking in Indonesia was severely lacking. On top of that, it appears that the Indonesian government's efforts towards this issue are still quite lagging compared with other countries. With this in mind, this paper aims to fill the gap by giving a comprehensive understanding of charging station's importance in broader EV development in Indonesia, and the role which the Indonesian government could contribute to advance this issue would also be examined. Thus, it would try to:

1. Understanding the relations between the development of charging stations and buyer's interest in purchasing an EV.

2. Determining some of the reasons why the interest in purchasing an EV in Indonesia is still lacking.

3. Assessing several policies which could be utilized to promote the development of publicly-funded charging stations in Indonesia.

4. Comprehending the implications of publicly funded charging stations that are widely available across all parts of Indonesia towards its sales of EV.

\section{Literature Review}

\subsection{Range Anxiety}


The issue of range anxiety still 'haunts' the public's interests towards EV adoption; particularly in a country with uneven charging stations distributions. The concept itself refers to a phenomenon in which an EV driver feels and perceived the sense of getting 'stranded' in their trips; both due to their vehicle's limited range (especially when compared to an ICE vehicle), and also to the lack of charging stations which could be access easily and nearby of them (Wardlaw 2020). Many pieces of research show a strong correlation between how range anxiety might significantly influence a buyer's mind to purchase an EV (Bastin, Bhattacharya, and Kumar 2019, 3; Preston 2020; Tshiesner et al. 2020, 22). Even though most buyers currently have acknowledged EV's various benefits compared to ICE vehicle (especially as EV technology had improved significantly), the issue of EV's range still affect future EV buyers decisively; in which a survey conducted within the United States (U.S.) shown that $71.7 \%$ of their respondents were more willing to purchase an EV when its charging stations are located not far from their workplace, or destinations of their trips (Bonges and Lusk 2016, 64). Although various research was still developed to further support this argument, it is widely believed and acknowledged by many policymakers that public funding provisions on charging stations development could influence buyer's decisions; as a study on German consumers estimates that a 10-30\% increase in charger availability might increase EV's demands by up to 50\% (Bailey, Miele, and Axsen $2015,2)$. In this context, the concept would be used to analyze how the Indonesian government might help to spark the consumer's interest to purchase an EV by subsidizing and providing public funding towards the development of new charging stations across the country.

\subsection{Chicken and Egg Problem}

The situation on relations between charging stations development and sales of EV has been commonly described as a 'chicken and egg problem'. This term implies a condition when potential EV users did not buy the vehicles since it is perceived to be lacking in its charging infrastructure, and at the same time, their counterparts (i.e. the suppliers of EV infrastructure) decided to wait for a larger market share of vehicles to maximize their business profits (Gnann, Plötz, and Wietschel 2015, 873). While it has been pointed out that a significant amount of public investment in developing a network of charging stations might not be needed (since it is assumed that EV buyers would utilize charging through private spaces; such as their homes or apartments), it remains as one of the biggest hindrances towards EV adoption; especially for potential and early users (Markkula, Rautiainen, and Jarventausta 2013, 1). In this regard, the concept would be used to highlight how the government's intervention on this issue might help to break the existing problem of economic scale; in which as of currently many in the private markets still believe that the prospects of EV development in Indonesia are perceived as too uncertain.

\subsection{The Entrepreneurial State/Market-Shaping}

This concept accentuates how government intervention is crucial to shaping the market at the earliest step, particularly in the context of a green transition. In novel and uncertain conditions, the private sector would not enter the market until coherent and systematic political signals have been communicated to them (Mazzucato 2014, 133). 
Additionally, the strong incumbency advantage makes them not judge that green transition is the main goal of their businesses. Therefore, to respond to this market failure, the government has to act resoundingly to ensure the investment made by the public sector would be followed by the private sector afterward. A firm stance from the government regarding the condition and clear long-term policy is a must for encouraging investors to take part in the market (Mazzucato 2014, 139). Aside from that, a comprehensive understanding of the market is required to implement an effective policy (Deleidi, Mazzucato, and Semieniuk 2020, 9). In this context, the concept would be used to analyze the importance of providing public funding towards economic sectors which are lacking in terms of private involvement. Ergo, the current market of gas stations to supply the petrol vehicle needs to be 'disrupted' to push for the greater adoption of EVs. This evolutionary step entailed competitiveness shaped by the government due to their advantage to not being dictated by the economy of scale of the markets, unlike its petrol counterparts.

With that being said, these three aforementioned concepts would be applied to analyze the interconnected nature between the lack of 1) EV charging stations within the country; 2) the private sectors' interest due to the perceived uncertainty on the existing legal framework and profit prospect in the future, and 3) a more intensive and thorough government's role within the matter.

\section{Research Methods}

This paper would be written using a qualitative approach that emphasizes literature study. Henceforth, the data itself will be collected through various sources which are regarded as relevant; with the likes of books, reports, journal articles, websites, etc. Some legal regulations which have been produced by various institutions within the Indonesian government would also be analyzed. We hypothesized that not only publicly funded the development of charging stations would be beneficial to the future-buyer of $\mathrm{EV}$, but also for the Indonesian government itself. In addition to that, the private sector would increase its participation within this industry once there is already certainty regarding the market structure which could further put forward the development of EV within the country.

\section{Results and Discussions}

The abysmally low rate of EV ownership in Indonesia could be traced to various factors, but most importantly it was also correlated with the country's even lower numbers of charging stations that its public could access. This reality made the Indonesian government's vision to increase it significantly in less than 10 years to come is unrealistic considering the current rate of its development. In this case, Indonesia's current trajectory is still lagging behind other commensurate countries in cultivating its EV share. Moreover, Indonesia itself represents a unique case due to its high concentration of motorcycles, especially in major cities. Currently, however, the sales of electric motorcycles within the country still fall short of the target being set up by the Ministry of Industry; although it had set the bar at 750,000 annual figure sales in 2020, its realization only achieved a mere number of 1,947 units (Junida 2021). This reality makes Indonesia need an adaptive strategy to cultivate the spread of EV's ownership proportion. 
Bringing to a broader context, several Association of Southeast Asian Nations (ASEAN) countries also have a typical condition. With that in mind, Indonesia as a de facto leader of this regional organization could seize the opportunity to lead the way for the other and make ASEAN an example for other regional areas. In addition, it could set itself as the 'trendsetter' of this issue within the region and would have the upper hand as an early adopter. Furthermore, Indonesia could set the bar for other community members and lay down the process of standardization with fellow ASEAN member states. Indeed, the window of opportunity should not be neglected considering that Indonesia and its neighbors did share similar challenges and problems within the issue of EV development.

A holistic approach is needed to not only giving attention to electric cars and motorcycles but also to other electric vehicles, such as buses, trucks, industrial vehicles, etc. Inevitably private vehicles in most cases will be charged in their respective residence and workplace. But for the aforementioned vehicles, public charging infrastructure is crucial for their ease of movement. In the longer term, the spatial constraint is a major problem that cities could not neglect. Consequently, the private-owned vehicle could be diminished gradually to continue the stimulation of public transport ridership. Most of the road-based public transportation have fixed routes, therefore making it much easier to plan EV charging points throughout the region in Indonesia.

It must be highlighted, also, that even though newer EV models might have shown a significant increase in the capabilities of their batteries, the concept of 'range anxiety' itself is still relevant when discussing the issue of various considerations which future EV buyers take into account should they seek to make a purchase. According to a survey in 2021, which are targeted towards vehicle consumer in the U.S., the factor of 'range' still reigns as the most important aspect; and such thinking was likewise reflected on the Overall Customer Satisfaction Index, which shows that EV buyers disproportionately perceive a vehicle with a higher range as better, rather than other factors such as reliability, driving experience or handling, etc. (Wardlaw 2020). Another study comparing twenty countries across the globe finds that charging infrastructure still remains to be pivotal, in addition to incentivizing EV acquisition through low financial incentives (Kotilainen et al. 2019, 589).

Reflecting this phenomenon towards the context of EV development in Indonesia, it could be posited that in order to attract (and to increase) future EV buyers, the concept of range anxiety did have its significance; and shall be taken into account in policy formulation by the Indonesian government. Since the government does not have the ability to 'intervene' thoroughly in the process of making a more efficient battery - as the single most fundamental part of an EV; what it could do to reduce the impact of range anxiety is by promoting the creation of charging stations that could be accessed easily and are prevalent across the country. Indonesia's current number of charging stations, however, still shows the lack of government efforts in this sector, and greater support would be much needed to change the trajectories of EV promotion programs within the country.

From the point mentioned above, it has become apparent that government interventions are needed to break the existing 'chicken and egg' problem. Hence, policy examples for this matter could be drawn from China and the U.S; which shows how such measures might be detrimental to push for greater conversion of ICE vehicles 
into EVs. Although both countries might have a different extent of government intervention, they did share the same goal which aims to increase the prevalence of charging stations and to encourage more EV buyers.

Looking into the Chinese model of development of its charging stations, its central government did play a major role as the 'catalyst' for EV development within the country; which includes setting out national targets and guidelines on EV matters, providing funding, and setting out specific standards that are implemented nationwide (Hove and Sandalow 2019, 26). However, local governments in China at provincial or municipal levels did also hold a certain role within the country's EV policymaking; albeit a limited one, which includes providing a specific financial incentive within their respective area, outlining guidelines for the provision of EV charging infrastructure at residential building or area, and mandating a certain percentage of parking lots to have a spot for charging stations.

Regarding its number, it is estimated that China has around 808,000 EV chargers; among 330,000 of them were designated for public usage (Hove and Sandalow 2019, 16). Even though the Chinese SOEs (and its government) still play as the major actors in this issue, recent efforts which call for cooperation have been made starting from 2014, and this opportunity has also been utilized by private investors as a means to increase the number of charging stations within the country. Besides that, various Chinese homegrown automakers who sell EVs within their line-up have also contributed significantly to this issue (Perkowski 2016). BYD, as an example, operates around 1,200 charging ports which are located in various Chinese cities as of 2018 (Hove and Sandalow 2019, 46).

Considering that China has finally 'solved' one of the barriers in this chicken and egg problem by intervening through the provisions of widely available charging stations, it has correlated positively with EV sales within the country. Furthermore, in the same year of 2015, China showed its EVs (and together with plug-in hybrids) sales to increase to more than 330,000 EV units (Perkowski 2016). Learning from China's case shows the option which Indonesia could emulate in order to break its ongoing chicken and egg problem that hampered its EV transition. In this sense, a policy that encouraged the creations of charging stations through government funding (or in cooperation with the private sectors) would be severely needed to increase buyer's interest in owning EVs compared to ICE vehicles.

In contrast with China, the development of charging stations infrastructure in the U.S. by its federal government in the past years could be described as 'minimum' at best, and instead relies significantly on the roles of state governments, local governments, and private sectors (especially car manufacturers) (Hove and Sandalow 2019, 29). Carmaker-owned networks are also far more prevalent in the U.S. compared to in China, in which brands such as Tesla, Nissan, and BMW currently dominate this sector. As an example, Tesla has around 595 locations of 'Superchargers' across the U.S. as of 2019, and more of them are expected to be constructed in the coming years (Hove and Sandalow 2019, 37). In 2020, it is estimated that there are around 1.8 million EVs which were registered in the U.S. However, when being compared with China that represents $44 \%$ of all the global EVs share in 2020, the U.S. only represents around $17 \%$ of it, out of the total figure of 10.2 million EVs worldwide. These 'disparities' have made the U.S. government seek to accelerate the increase of EV share within the country, especially amidst the fact that EVs only accounted for $2 \%$ of the new-car market within the U.S from 2017 to 2020 (Desilver 2021). 
Through the announcement of The American Jobs Plan in 2021 by the Biden administration, the U.S. federal government has stated it would provide a mechanism for incentive programs that were intended for both state and local governments; as well as the country's private sector, by 2030 to build a network of 500,000 EV chargers ("FACT SHEET: The American Jobs Plan" 2021). The private sector within the U.S. has also tried to move swiftly in midst of these changes. As an example, General Motors (GM) has stated that 3 of its plants would be scheduled to only produce EVs in 2021, while Tesla has a plan to add one more factory (Kolodny 2021). This phenomenon shows that the public expectations for government intervention in this issue have become more and more relevant, and are critically needed. Moreover, it shows how government support might help to spur the interest from the private actors to invest more within the industry.

Other than that, public-funded EV charging infrastructure should likewise be manifested in collaboration among relevant SOEs. PLN and Pertamina as such are the key players in this cooperation. In this sense, both entities have their own strengths and weaknesses. On one hand, Pertamina currently owns more than $96 \%$ of the total petrol stations in Indonesia which could be the fast-track to ensuring the widespread availability of charging stations (Agustinus 2018). On the other hand, PLN as a state electricity supplier has the upper hand of having the electricity know-how. Land availability which often becomes one of the most significant obstacles in major cities could be overcome by this synergy.

Petrol stations would be a thing of the past in the near future. Pertamina urgently needs to change its course in order to stay relevant in this matter. The current business model that Pertamina implemented relies heavily on the sales of petrol in the gas station is far from sustainable to maintain its relevance. In this regard, evaluating whether the current state of a gas station is feasible to fully convert to a charging station is paramount. The market equilibrium is important to minimize any potential cost that could hurt the financial sheets of the supplier and at the same time build an absolute sense of peace of mind for EV's owner.

A gradual transition is essential for both sides in converting the gas nozzle to electric charge to make it a sustainable practice and giving a firm signal to the private sector that the business of charging infrastructure is a lucrative one. Become the market shaper, the dynamic duo could further set the bar for the others which could be beneficial for their business sustainability. From the future owner's perspective, the transformation of petrol stations to an SPKLU could make it easier to map the place to fill up their EV. It must also be kept in mind, however, that such a conversion process would be impacted by the demands which exist within the market since not all types of SPKLU are created equal.

Table. 2 Type of SPKLU

\begin{tabular}{|c|c|}
\hline SPKLU Level & Power Outputs (on kilowatts or kw) \\
\hline Level 1 & Less than 3.7 \\
\hline Level 2 & Less than 22 \\
\hline Level 3 & Less than 50 \\
\hline
\end{tabular}




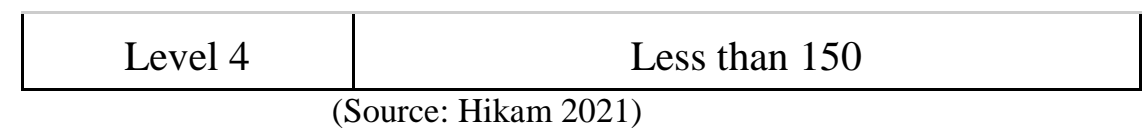

This capital-intensive investment could be a workaround by the standardization of each charging station across Indonesia. Taking a lesson from Denmark, they reduced their network externalities by implementing nationwide European Union (EU) technical standards (Kotilainen et al. 2019, 579). The standardization would be useful to ensure there would be a level playing field once the private sector jumps into the market. Preventing any externalities that could happen would give further certainty in this segment. Another prime example to highlight the importance of developing standardized charging infrastructure could also be drawn from the case of Finland; in which if being compared with its Nordic fellows, did have a lower adoption rate of EVs - which contrast to Denmark, they have yet to implement the EU technical standards (Kotilainen et al. 2019, 589).

However, the EV charging station itself must adapt to future development. Prospective wireless charging that could disrupt the charging point business must be considered from the very beginning. The cable-free technology opens up other opportunities to maximize open space that is underutilized due to the recent research that shows that this new kind of charging does not need that close enough with the charger - unlike the existing smartphone wireless charging (The Economist 2020). EV itself has progressed at a rapid pace over the years, therefore the rate should be tantamount to the charging station planning and business model.

This standardization should also include both plug-in and battery swap technology. Current fragmentation confuses many to differentiate between SPKLU and SPBKLU. Right now, there still is not any standardization among manufacturers regarding battery specification for exchange practice, but a recent initiative by a few major motorcycle manufacturers to streamline their battery signified the need for firm regulation (Toll 2020). Thus, adaptive measures should be taken from the earliest stage to ensure minimizing range anxiety plagued $\mathrm{EV}$ potential owners due to the common confusion that surrounds them. Alongside that, the standardization is not just about the charger. Amenities that supplement the charging stations should be streamlined. Besides, it opens up a window of opportunity to make self-service become a common practice to recharge their own vehicle-which in Indonesia to date this practice is still yet to be ubiquitous.

\section{Conclusions and Recommendations}

\subsection{Conclusions}

The Indonesian government must and should seize the moment to multiply EV ownership by funding the charging station nationwide. Taking lessons from other countries - in particular, the differences that divide between China and the U.S - and several others that are already many steps ahead of Indonesia, proves that a publicfunded charging station is crucial to alleviate the chicken and egg problem in transforming ICE to EV ownership. The range anxiety that still haunts the public has hampered the growth of EVs, and will not vanish by itself. This green transition needs to be shaped by the public sector at the first step before persuading the private sectors 
to jump into the market. In this sense, SOEs have an important role to translate the government's vision into action. Furthermore, it is hoped that once the government support has been poured more intensively, the private sectors would follow soon and might increase both of their EV productions, as well as invest more in the development of charging stations; both by themselves or through a PPP (publicprivate partnership). Eventually, there will be a shift from range anxiety disease to range confidence serenity which positively impacts EV ownership in Indonesia.

\subsection{Recommendations}

1) Pushing for government's concrete roles in the development of charging stations;

2) Formulating a clearer legal framework that seeks to diminish the current barriers of EV ownerships;

3) Pushing for uniformization of Indonesia's charging plug standards;

4) Intensify collaboration among related SOEs to implement the government's policy;

5) Further studies needed to be conducted to assess the evolving conditions from many years to come. 


\section{Bibliography}

\section{Books}

Adiatma, Julius Christian, and Idoan Marciano. 2020. "The Role of Electric Vehicles in Decarbonizing Indonesia's Road Transport Sector.” Climate Transparency. Jakarta: Institute for Essential Services Reform (IESR).

Gnann, Till, Patrick Plötz, and Martin Wietschel. 2015. "How to Address the Chicken-EggProblem of Electric Vehicles? Introducing an Interaction Market Diffusion Model for EVs and Charging Infrastructure." Karlsruhe: Fraunhofer Institute for Systems and Innovation Research ISI.

Mazzucato, Mariana. 2014. The Entrepreneurial State: Debunking Public vs. Private Sector Myths. Revised edition. Anthem Frontiers of Global Political Economy. London; New York: Anthem Press.

\section{Government Documents}

Kementerian ESDM. Permen ESDM No. 13 Tahun 2020 tentang Penyediaan Infrastruktur Pengisian Listrik Untuk Kendaraan Bermotor Listrik Berbasis Baterai. Dokumen Pemerintah, Jakarta: Kementerian ESDM Indonesia.

Kementerian Sekretariat Negara Republik Indonesia. Peraturan Presiden Nomor 55 Tahun 2019 tentang Percepatan Program Kendaraan Bermotor Listrik Berbasis Baterai (Battery Electric Vehicle) untuk Transportasi Jalan. Dokumen Pemerintah, Jakarta: Kementerian Sekretariat Negara Republik Indonesia.

Kementerian Sekretariat Negara Republik Indonesia. Peraturan Pemerintah Nomor 73 Tahun 2019 tentang Barang Kena Pajak yang Tergolong Mewah Berupa Kendaraan Bermotor yang Dikenai Pajak Penjualan atas Barang Mewah. Dokumen Pemerintah, Jakarta: Kementerian Sekretariat Negara Republik Indonesia.

\section{Journals and Articles}

Bailey, Joseph, Amy Miele, and Jonn Axsen. 2015. "Is Awareness of Public Charging Associated with Consumer Interest in Plug-in Electric Vehicles?" Transportation Research Part D: Transport and Environment 36 (May): 1-9. https://doi.org/10.1016/j.trd.2015.02.001.

Bonges, Henry A., and Anne C. Lusk. 2016. "Addressing Electric Vehicle (EV) Sales and Range Anxiety through Parking Layout, Policy and Regulation." Transportation Research Part A: Policy and Practice 83 (January): 63-73. https://doi.org/10.1016/j.tra.2015.09.011.

Deleidi, Matteo, Mariana Mazzucato, and Gregor Semieniuk. 2020. "Neither Crowding in nor out: Public Direct Investment Mobilising Private Investment into Renewable Electricity Projects.” Energy Policy $140 \quad$ (May): 111195. https://doi.org/10.1016/j.enpol.2019.111195.

Hove, Anders, and David Sandalow. 2019. "Electric Vehicle in China and the United States." New York: Center on Global Energy Policy School of International and Public Affairs Columbia University. https://energypolicy.columbia.edu/sites/default/files/fileuploads/EV_ChargingChina-CGEP_Report_Final.pdf.

Kimura, Shigeru, Shigeru Suehiro, and Naoko Doi. 2018. "An Analysis of Alternative Vehicles' Potential and Implications for Energy Supply Industries in Indonesia." 15. ERIA Research Project FY2017. ERIA. 
Kotilainen, Kirsi, Pami Aalto, Jussi Valta, Antti Rautiainen, Matti Kojo, and Benjamin K. Sovacool. 2019. "From Path Dependence to Policy Mixes for Nordic Electric Mobility: Lessons for Accelerating Future Transport Transitions." Policy Sciences 52 (4): 573 600. https://doi.org/10.1007/s11077-019-09361-3.

Markkula, Joni, Antti Rautiainen, and Pertti Jarventausta. 2013. "The Business Case of Electric Vehicle Quick Charging \&\#x2014; No More Chicken or Egg Problem.” In 2013 World Electric Vehicle Symposium and Exhibition (EVS27), 1-7. Barcelona, Spain: IEEE. https://doi.org/10.1109/EVS.2013.6915043.

\section{Websites}

Agustinus, Michael. 2018. "RI Punya 7.455 SPBU, 51\% di Jawa Madura dan Bali." kumparan. March 19, 2018. https://kumparan.com/kumparanbisnis/ri-punya-7-455-spbu-51-dijawa-madura-dan-bali.

Alaidrus, Fadiyah. 2019. "Dinas LH: 75 Persen Penyebab Polusi Udara Jakarta Emisi Kendaraan.” Tirto.Id. July 3, 2019. https://tirto.id/dinas-lh-75-persen-penyebab-polusiudara-jakarta-emisi-kendaraan-edyc.

Asmarini, Wilda. 2020. "Apa Benar RI Kelebihan Pasokan Listrik? Ini Penjelasan PLN." CNBC Indonesia. Oktober 2020. https://www.cnbcindonesia.com/news/20201005151241-4-191991/apa-benar-rikelebihan-pasokan-listrik-ini-penjelasan-pln.

CNN Indonesia. 2021. "Daftar Mobil Listrik Dan Hybrid Terlaris Di Indonesia 2020." Teknologi. January 22 , 2021. https://www.cnnindonesia.com/teknologi/20210122094816-384-597013/daftarmobil-listrik-dan-hybrid-terlaris-di-indonesia-2020.

Dawborn, David, Jeanne Elisabeth Donauw, and Justikarini Sormin. 2019. “One Step Forward for Battery-Powered Electric Vehicles in Indonesia." Herbert Smith Freehills. September 3, 2019. https://www.herbertsmithfreehills.com/latest-thinking/one-stepforward-for-battery-powered-electric-vehicles-in-indonesia.

Desilver, Drew. 2021. "Today's Electric Vehicle Market: Slow Growth in U.S., Faster in China, Europe." Pew Research Center. June 7, 2021. https://www.pewresearch.org/fact-tank/2021/06/07/todays-electric-vehicle-marketslow-growth-in-u-s-faster-in-china-europe/.

"FACT SHEET: The American Jobs Plan." 2021. The White House. March 31, 2021. https://www.whitehouse.gov/briefing-room/statements-releases/2021/03/31/factsheet-the-american-jobs-plan/.

Guild, James. 2020. “Jokowi's 35000 Megawatt Dream.” Inside Indonesia. Oktober 2020. https://www.insideindonesia.org/jokowi-s-35000-megawatt-dream.

Hikam, Herdi Alif Al. 2021. "Jumlah SPBU Listrik di Indonesia Tembus 100, Ini Sebarannya." detikfinance. February 10, 2021. https://finance.detik.com/energi/d-5369044/jumlahspbu-listrik-di-indonesia-tembus-100-ini-sebarannya.

Junida, Ade Irma. 2021. "Indonesia Perlu Belajar Dari Tiga Negara Ini Dorong Kendaraan Listrik." Antara News. February 23, 2021. https://www.antaranews.com/berita/2013927/indonesia-perlu-belajar-dari-tiganegara-ini-dorong-kendaraan-listrik.

Kolodny, Lora. 2021. "The U.S. Is Falling Further behind China and Europe in Electric-Vehicle Production.” CNBC. June 29, 2021. https://www.cnbc.com/2021/06/29/the-us-isfalling-further-behind-china-and-europe-in-ev-production.html.

Kurniawan, Ruly. 2021. "Ini Daftar Tempat Ngecas Kendaraan Listrik di Indonesia." KOMPAS.com. January 7 , 2021 https://otomotif.kompas.com/read/2021/01/07/071200515/ini-daftar-tempat-ngecas- 
kendaraan-listrik-di-indonesia.

Nurcahyani, Ida. 2021. "Penjualan Mobil 2020 Dan Daftar Merek Terlaris." Antara News. January 16, 2021. https://otomotif.antaranews.com/berita/1949576/penjualan-mobil2020-dan-daftar-merek-terlaris.

Perkowski, Jack. 2016. "The Electric Car Market Has A 'Chicken Or Egg' Problem -- And China Is Solving It.” Forbes. September 26, 2016. https://www.forbes.com/sites/jackperkowski/2016/09/26/china-electric-car-chargingstation/.

Rahadiansyah, Rangga. 2021. "Segini Penjualan Mobil Listrik di Indonesia.” detikoto. January 23, 2021. https://oto.detik.com/mobil/d-5345739/segini-penjualan-mobil-listrik-diindonesia.

“TaxFlash.” 2019. 17. Jakarta: PwC.

The Economist. 2020. "Wireless Charging of Electric Cars Looks Increasingly Promising," May 14, 2020. https://www.economist.com/science-and-technology/2020/05/14/wirelesscharging-of-electric-cars-looks-increasingly-promising.

Toll, Micah. 2020. "Honda, Yamaha, Kawasaki, and Suzuki Test Shared Swappable Electric Motorcycle Batteries." Electrek. September 4, 2020. https://electrek.co/2020/09/04/honda-yamaha-kawasaki-suzuki-test-swappableelectric-motorcycle-batteries/.

UNFCCC. 2016. "First Nationally Determined Contribution Republic of Indonesia."

Wardlaw, Christian. 2020. "What Is Range Anxiety with Electric Vehicles?" J.D. Power. November 3, 2020. https://www.jdpower.com/cars/shopping-guides/what-is-rangeanxiety-with-electric-vehicles. 